\title{
INFESTATION OF NEMATODE PARASITE FILOCHONA TELEOSTEI IN RELATION TO SIZE, WEIGHT AND AGE OF SNOW TROUT SCHIZOTHORAX RICHARDSONII (GRAY)
}

\author{
Omveer Singh $^{1 *}$ and Shweta Panwar ${ }^{2}$ \\ ${ }^{1}$ Department of Zoology, Sahu Jain College, Najibabad-246763(U.P.), India \\ ${ }^{2}$ Centre for Biomedical Engineering, Indian Institute of Technology Delhi, Hauz Khas, New Delhi, \\ 110016, India
}

*Corresponding Author Email id: drovsgill@gmail.com

Received: 02.10.2020; Revised: 20.10.2020; Accepted: 13.11.2020

(C)Society for Himalayan Action Research and Development

\begin{abstract}
Parasitological investigation was conducted to assess the effects of various biotic factors viz. length, weight and age of host on the infection patterns of Filochona teleostei (Singh \& Malik, 1992) in snow trout Schizothorax richardsonii (HAM.) from hill streams of Garhwal Himalayas. The statistical analysis was carried out to calculate infection incidence, mean worm burden, regression values and their significance. About $20 \%$ fishes (18\% male and $22 \%$ female) were found infected with nematode parasites. Infection patterns of Filochona teleostei revealed a negative correlation ( $r=-0.347$ to -0.734$)$ with length, $(r=-0.499$ to -0.671$)$ with weight and $(r=-0.576)$ with age of host fish. The age immunity and stronger host resistance developed by the larger fishes are the possible reasons for the decrease in infection in larger and older fishes.
\end{abstract}

Keywords: Nematode parasite, Filochona, Snow trout, infection incidence, host size, host age

\section{Introduction}

Fishes are found abundantly in all natural waters. They provide a good protein rich source of diet for man especially in Garhwal Himalayan region of India, where a small amount of land is suitable for agriculture. The main fishery resources of Uttrakhand are rivers and their tributaries, high and low altitude natural lakes, man-made reservoirs and ponds. Trout and mahseer are local fishes of commercial value. The growth of these fishes depends upon various environmental factors including helminth parasites (Iwanowicz, 2011). The infection of helminth parasites in relation to host length, weight and sex have been studied earlier by Smyth (1962), Thomas (1964) for Salmo trutta, Arme and Owen (1967) for Gastrosteus aculeatus, Borowik (1968) for Alburnus alburnus, kennedy and walker (1969) for Leuciscus leuciscus, Lawrence (1970) for
Catostomus commersoni, Chauhan (1982) for Barilius bola and Tor tor, Scholz (1986) for Perca fluviatilis, Frandsen et al. (1989) for Salvelinus alpinus(L.), Robert et al. (1990) for Anguilla spp., Saad-Fares and Combes (1992) for Diplodus vulgaris. Recently Khanum and Parveen (1997) for Macrognathus armatus, Khanum et al. (2011) for Macrognathus aculeatus, Parveen and Sultana (2014) for Nandus nandus and Abiyu et al. (2020) for Oreochromis niloticus conducted similar studies. Little work has been done on the nematode parasites and fish host relationship especially in the context of Garhwal Himalayas (Singh and Malik, 1990). Present study provides the knowledge of infection incidence and intensity of nematode parasites in relation to length, weight and age of snow trout Schizothorax richardsoni. 


\section{Materials and methods}

Present investigation was conducted on more than 450 specimens of Schizothorax richardsonii (Gray) collected from river Alaknanda (525 mASL) near Srinagar (Garhwal) during 20142016. The fishes were collected by netting method with the help of local fishermen. Each fish was identified, measured and weighed before autopsy. Male and female fishes identified according to Sharma and Mehta (2010). The age of fish was determined by scale method according to Lux (1971). After dissection, roundworms (Filochona) were collected from different parts of the alimentary canal and body cavity. Complete worms were killed in lukewarm water, fixed in hot $70 \%$ alcohol and glycerine (95: 5). Parasites were cleared and mounted in lacto-phenol, camera lucida drawings were prepared and identified (Singh and Malik ,1992). Fishes were separated into six standard length groups ( $<16.0,16.1-18.0,18.1-20.0,20.1-22.0$, $22.1-24.0$ and $>24.1 \mathrm{~cm})$ six body weight classes $(<80.0,80.1-110.0, \quad 110.1-140.0,140.1-170.0$, $170.1-200.0$ and $>200.1 \mathrm{gm})$ five age classes $(<1$, $1-2,2-3,3-4$ and $>4$ years). Following formulae were used for statistical analysis of various correlations and other calculations in the present investigation.

1. Coefficient of correlation (Snedecor and Cochran, 1968)

$$
r=\frac{\sum d x \cdot d y-\left(\frac{\sum d x \sum d y}{n}\right)}{\sqrt{\left(\sum d x^{2}-\frac{\left(\sum d x\right)^{2}}{n}\right)\left(\sum d y^{2}-\frac{\left(\sum d y\right)^{2}}{n}\right)}}
$$

where, ${ }^{\sum d x \sum d x}=$ sum of deviations of the variations (x) from its assumed mean.

$\sum d y \sum d y=$ sum of deviations of the variations

(y) from its assumed mean.

$\mathrm{n}=$ total number of items.

Dominance percentage $=\frac{\text { Total worm burden for the month } \mathrm{x} 100}{\text { Total worm burden for the year }}$
Dominance percentage $=\frac{\text { Total worm burden for the month } \mathrm{x} 100}{\text { Total worm burden for the year }}$

3. Incidence (\%) (Malhotra, Chauhan and Capoor, 1980)
Incidence $(\%)=\frac{\text { Number of infected fish }}{\text { Number of examined fish }} \times 100$

4. Incidence of infection (Snedecor and Cochran, 1968)

$=\frac{\text { Number of worms } \times \text { Number of infected fishes }}{(\text { Number of fishes examined })^{2}}$

5. Linear Regression Equation (Snedecor and Cochran, 1968)

$\mathrm{Y}=\alpha y x+\beta y x \cdot x$

where, $\alpha y x=y-$ intercept

$\beta \mathrm{yx}=$ slope predicting $\mathrm{y}$ from $\mathrm{x}$ (OR)

where, $a=y-b x$

$$
y=a+b x
$$

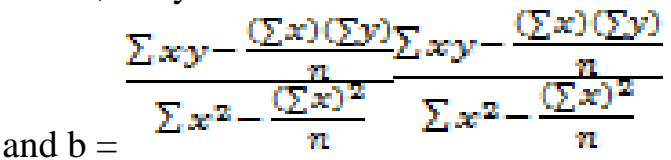

$y$. $x$. are the mean variables of $y$ and $x$ respectively and

$\mathrm{n}=$ number of observations.

\section{Results and discussion}

Infection data for Filochona teleostei in Schizothorax richardsonii revealed a significant inverse relationship between incidence and fish length ( $p>0.25$ to $p>0.025)$. The higher infestations were observed in small size fishes in 2014-15 (Fig. 1) (male $16.1-18.0 \mathrm{~cm}$, female $<16.0 \mathrm{~cm}$ ), then incidence decreased regularly in larger male fish and with fluctuations in female fish. In 2015-16 (Fig. 2) the middle-sized fishes (male 20.1-22.0 $\mathrm{cm}$, female and total $18.1-20.0 \mathrm{~cm}$ ) were found heavily infested than smaller and larger fishes. The mean worm burden did not show any definite correlation with fish length, as in 2014-15, it increased insignificantly $(\mathrm{p}<0.10)$ with an increase in fish length, while in 2015-16 the mean worm burden declined significantly ( $\mathrm{p}<0.001)$ (Fig. 2). The highest mean worm burden in 2015-16 was observed in smaller fishes but in 2014-15 in relatively larger length classes. An analysis of regression, coefficient of correlation and level of significance have been summarized in Table 1 . 
Table 1: Regression Values illustrating the influence of length of $S$. richardsonii on the infection patters of F. teleostei.

\begin{tabular}{|c|c|c|c|c|}
\hline & \multicolumn{2}{|c|}{ Regression equation } & \multirow{2}{*}{$\begin{array}{l}\text { Coefficient of correlation }(\mathbf{r}) \\
\text { Incidence }\end{array}$} & \multirow[t]{2}{*}{ Level of significance $(p)$} \\
\hline & & & & \\
\hline \multirow[t]{3}{*}{ 2014-15 } & Male & $Y=37.911-0.762 X$ & -0.321 & $\mathrm{p}>0.20$ \\
\hline & Female & $Y=34.642-0.517 X$ & -0.241 & $\mathrm{p}>0.25$ \\
\hline & Total & $Y=37.373-0.664 X$ & -0.347 & $\mathrm{p}>0.20$ \\
\hline \multirow[t]{3}{*}{$2015-16$} & Male & $Y=36.259-0.717 \mathrm{X}$ & -0.717 & $\mathrm{p}<0.025$ \\
\hline & Female & $Y=60.390-1.916 X$ & -0.682 & $\mathrm{p}<0.025$ \\
\hline & Total & $Y=45.825-1.405 X$ & -0.734 & $\mathrm{p}<0.025$ \\
\hline \multicolumn{5}{|c|}{ Mean worm burden } \\
\hline \multirow[t]{3}{*}{ 2014-15 } & Male & $Y=1.782+0.007 X$ & 0.038 & $\mathrm{p}>0.45$ \\
\hline & Female & $Y=4.213+0.019 X$ & 0.073 & $\mathrm{p}>0.40$ \\
\hline & Total & $Y=2.172+0.062 X$ & 0.494 & $\mathrm{p}<0.10$ \\
\hline \multirow[t]{3}{*}{ 2015-16 } & Male & $Y=3.775-0.112 X$ & -0.262 & $\mathrm{p}>0.25$ \\
\hline & Female & $Y=6.805-0.223 X$ & -0.836 & $\mathrm{p}<0.001$ \\
\hline & Total & $Y=5.380-0.116 X$ & -0.936 & $\mathrm{p}<0.001$ \\
\hline
\end{tabular}

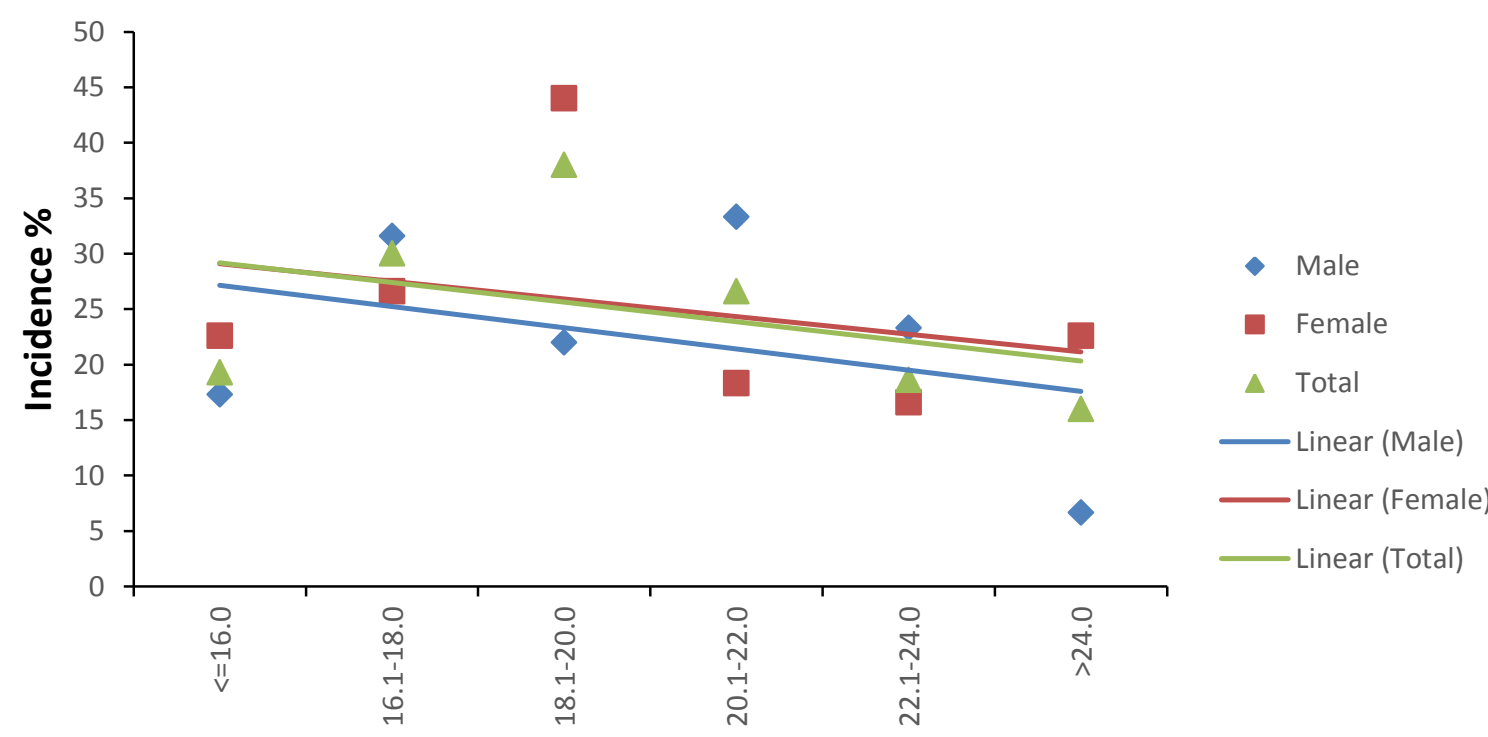

Fish Length $(\mathrm{cm})$

Fig 1(a): Correlation of infection incidence (a) of F. teleostei with length of S. richardsonii during 201415

Statistical analysis revealed a significant $(\mathrm{p}>0.35$ to $<0.05$ ) inverse correlation between incidence of $F$. teleostei and weight of $S$. richardsonii.
Incidence showed fluctuations and there was no stability between successive weight classes. 


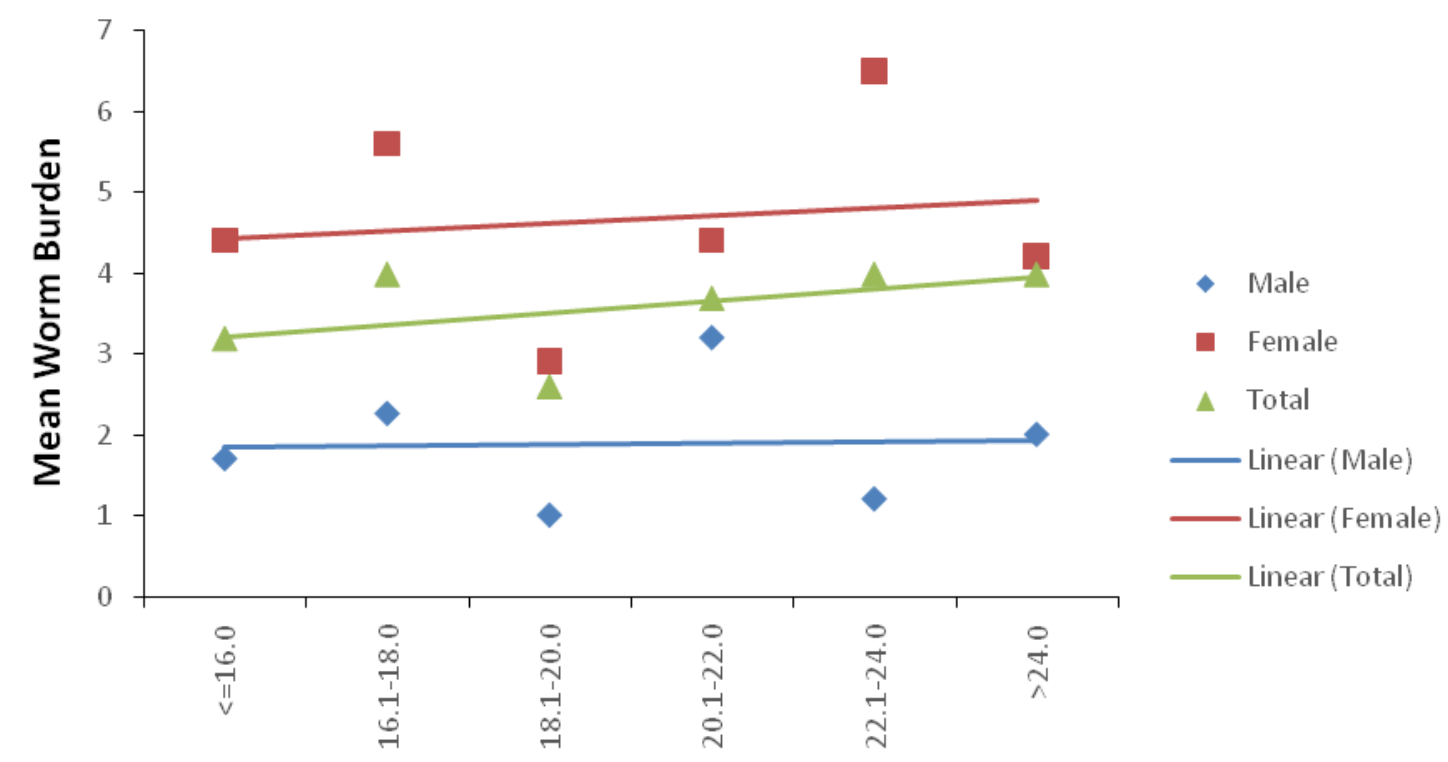

Fish Length $(\mathrm{cm})$

Fig 1 (b): Correlation of mean worm burden (b) of F. teleostei with length of S. richardsonii during 201415

Table 2: Regression Values illustrating the influence of weight of $S$. richardsonii on the infection patters of F. teleostei.

\begin{tabular}{|c|c|c|c|c|}
\hline & \multicolumn{2}{|c|}{ Regression equation } & \multirow{2}{*}{$\begin{array}{l}\text { Coefficient of correlation }(r) \\
\text { Incidence }\end{array}$} & \multirow{2}{*}{ Level of significance (p) } \\
\hline & & & & \\
\hline \multirow[t]{3}{*}{$2014-15$} & Male & $Y=25.911-0.015 X$ & -0.135 & $\mathrm{p}>0.35$ \\
\hline & Female & $Y=43.132-0.106 \mathrm{X}$ & -0.607 & $\mathrm{p}<0.10$ \\
\hline & Total & $Y=35.162-0.069 X$ & -0.671 & $\mathrm{p}<0.05$ \\
\hline \multirow[t]{3}{*}{$2015-16$} & Male & $Y=26.911-0.015 X$ & -0.661 & $\mathrm{p}<0.05$ \\
\hline & Female & $Y=29.432-0.044 X$ & -0.257 & $\mathrm{p}>0.25$ \\
\hline & Total & $Y=26.346-0.045 X$ & -0.499 & $\mathrm{p}>0.15$ \\
\hline \multicolumn{5}{|c|}{ Mean Worm Burden } \\
\hline \multirow[t]{3}{*}{$2014-15$} & Male & $Y=2.548-0.002 X$ & -0.174 & $\mathrm{p}>0.35$ \\
\hline & Female & $Y=3.688+0.003 X$ & 0.241 & $\mathrm{p}>0.30$ \\
\hline & Total & $Y=3.230+0.006 X$ & 0.050 & $\mathrm{p}>0.45$ \\
\hline \multirow[t]{3}{*}{$2015-16$} & Male & $Y=2.664-0.009 X$ & -0.747 & $\mathrm{p}<0.05$ \\
\hline & Female & $Y=4.079-0.013 X$ & -0.564 & $\mathrm{p}<0.05$ \\
\hline & Total & $Y=3.566-0.009 X$ & -0.733 & $\mathrm{p}<0.025$ \\
\hline
\end{tabular}

In 2014-15, (Fig. 3) the maximum incidence occurred in moderately heavier fishes (male 140.1-170.0gm, female and total 110.1-140.0gm); while during 2015-16, maximum incidence was noted from lighter fishes $(<80.0 \mathrm{gm})$ in both sexes (Fig. 4). The heavier males $>200.1$ gm were free of infection. In females, the incidence decreased up to the lowest level in fishes of 140.1$170.0 \mathrm{gm}$, then increased in heavier fishes. However, in total (male and female) fishes, the incidence was almost stable in all fishes of $>140.1$ gm body weight.

Mean worm burden exhibited different patterns in both sexes in 2015-16 (Fig. 3). 


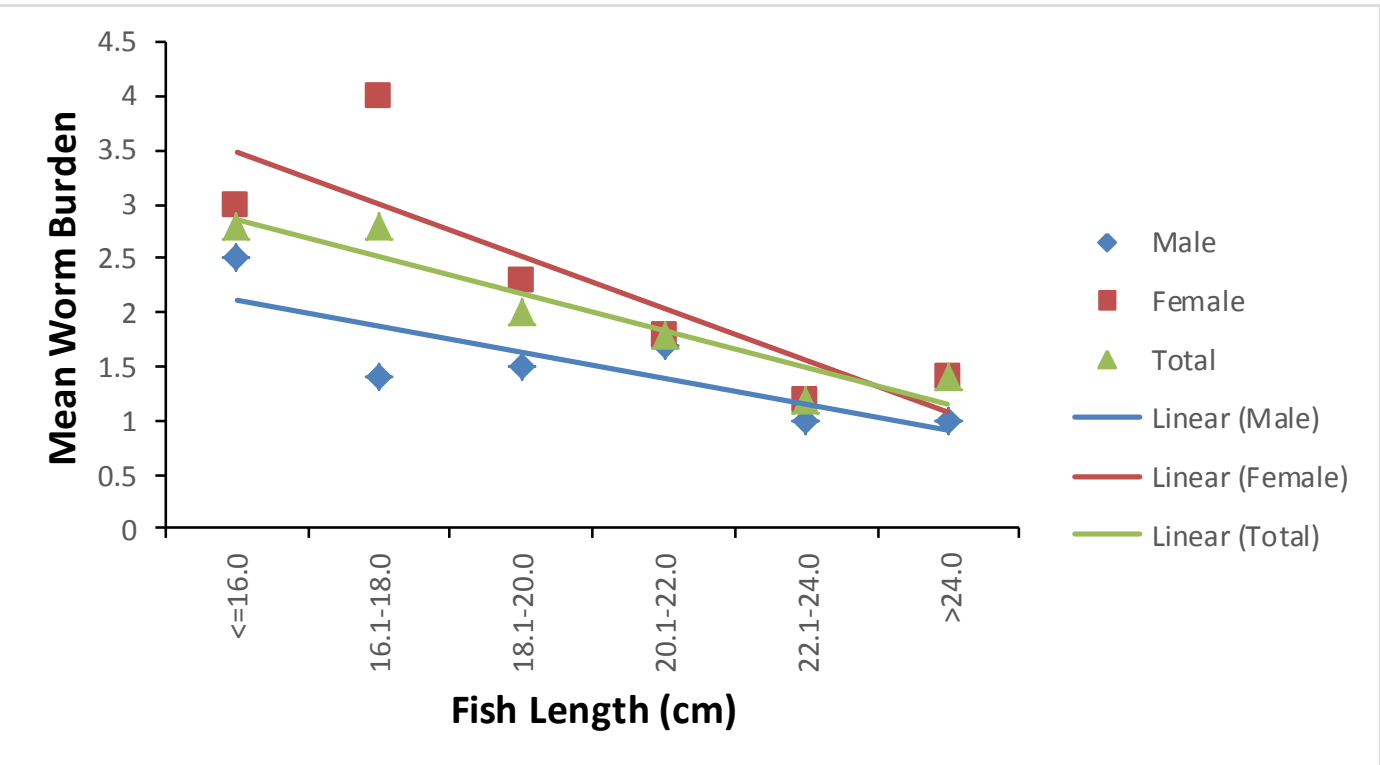

Fig 2 (b): Correlation of mean worm burden of F. teleostei with length of S. richardsonii during 2015-16

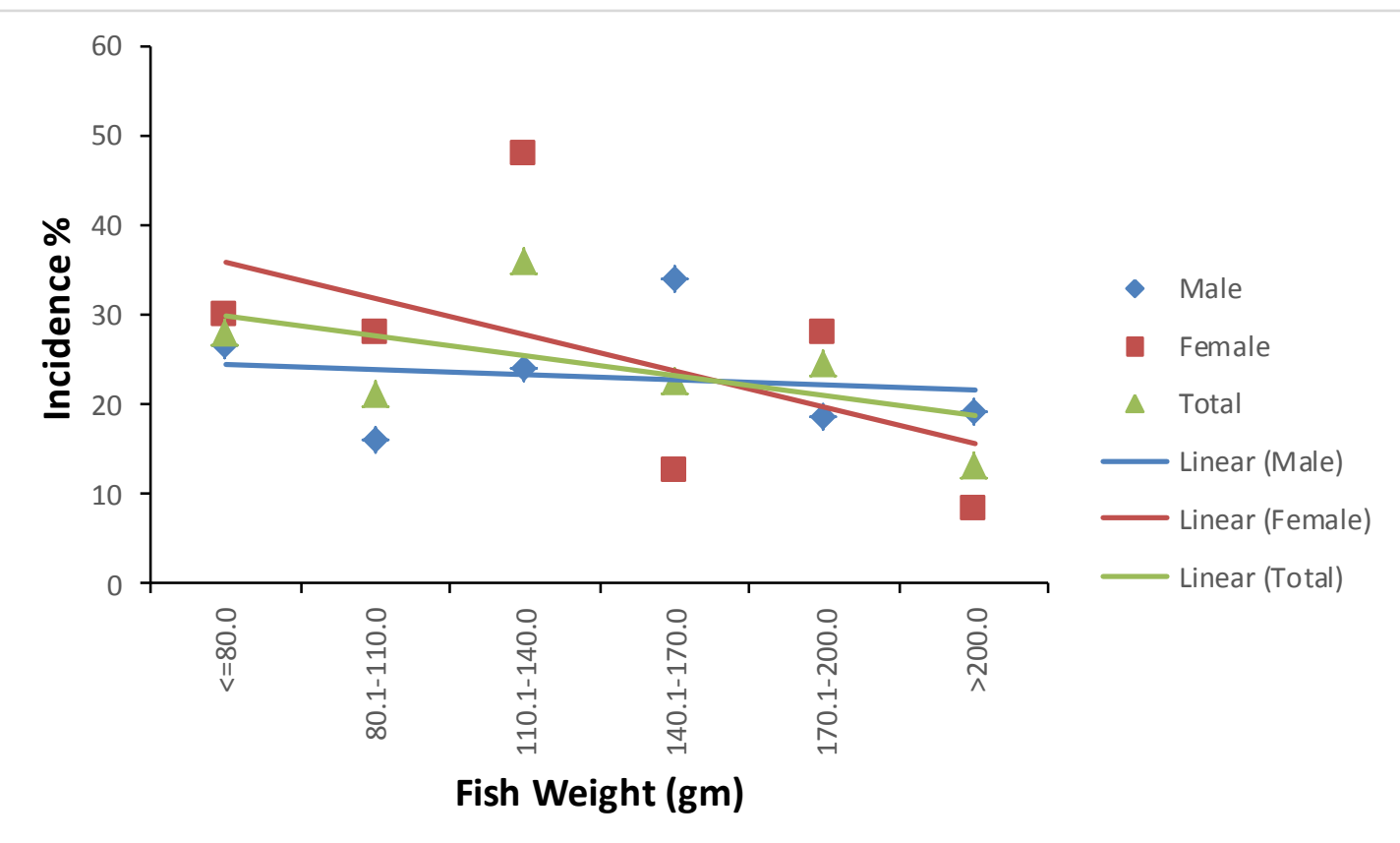

Fig 3 (a): Correlation of infection incidence of $F$. teleostei with weight of S. richardsonii during 2014-15 


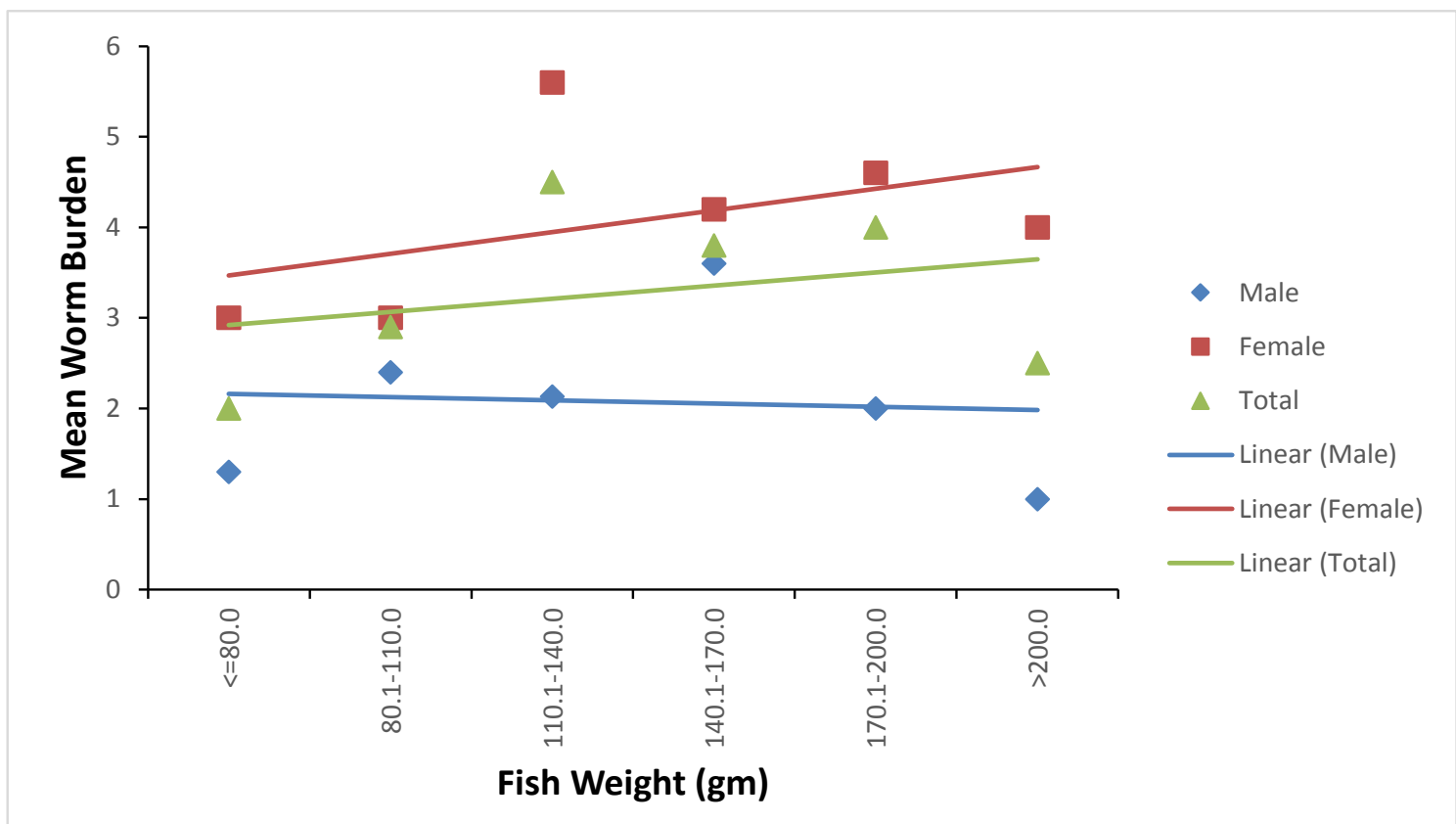

Fig 3 (b): Correlation of mean worm burden of F. teleostei with weight of S. richardsonii during 2014-15

In male fish the analysis of regression showed that the mean worm burden decreased slowly with the increase in fish weight but in female fish it increased. However, in fishes of both sexes, the incidence was found maximum in middle weight classes (male 140.1-170.0 gm; female and total 110.1-140.0gm) and minimum in lighter or heavier fishes. During 2015-16 (Fig. 4), the correlation was negative in both sexes. Lighter fish $(<80.0 \mathrm{gm})$ showed maximum mean worm burden while heavy fish ( $>200.1 \mathrm{gm})$ were free of infection. An analysis of linear regression, coefficient of correlation and level of significance for both years is given in Table 2 .

The infection incidence for $F$. teleostei showed a significant negative correlation with age of host (Fig. 5, Table 3). The minimum incidence of infection was observed in the age group of 3-4 years, then increased due to the fact that very few large specimens were collected and most of them were found infected. On the other hand, mean worm burden did not show significant negative correlation with age of fish. In general, it showed oscillations in different age groups.

Table 3: Regression Values illustrating the influence of age of $S$. richardsonii on the infection patters of F. teleostei during 2014-16

\begin{tabular}{ccccc}
\hline \multicolumn{4}{c}{ Regression equation } & \multicolumn{2}{c}{ Coefficient of correlation $(\mathbf{r})$} & Level of significance $(\mathbf{p})$ \\
\hline Male & $\mathrm{Y}=23.011-2.739 \mathrm{X}$ & -0.657 & $\mathrm{p}<0.10$ \\
Female & $\mathrm{Y}=29.787-3.323 \mathrm{X}$ & -0.753 & $\mathrm{p}<0.05$ \\
Total & $\mathrm{Y}=26.765-3.019 \mathrm{X}$ & -0.576 & $\mathrm{p}<0.05$ \\
& \multicolumn{4}{c}{ Mean Worm Burden } \\
Male & $\mathrm{Y}=1.902-0.182 \mathrm{X}$ & -0.182 & \\
Female & $\mathrm{Y}=3.782+0.269 \mathrm{X}$ & -0.532 & $\mathrm{p}>0.35$ \\
Total & $\mathrm{Y}=3.049+0.166 \mathrm{X}$ & -0.654 & $\mathrm{p}<0.10$ \\
\end{tabular}




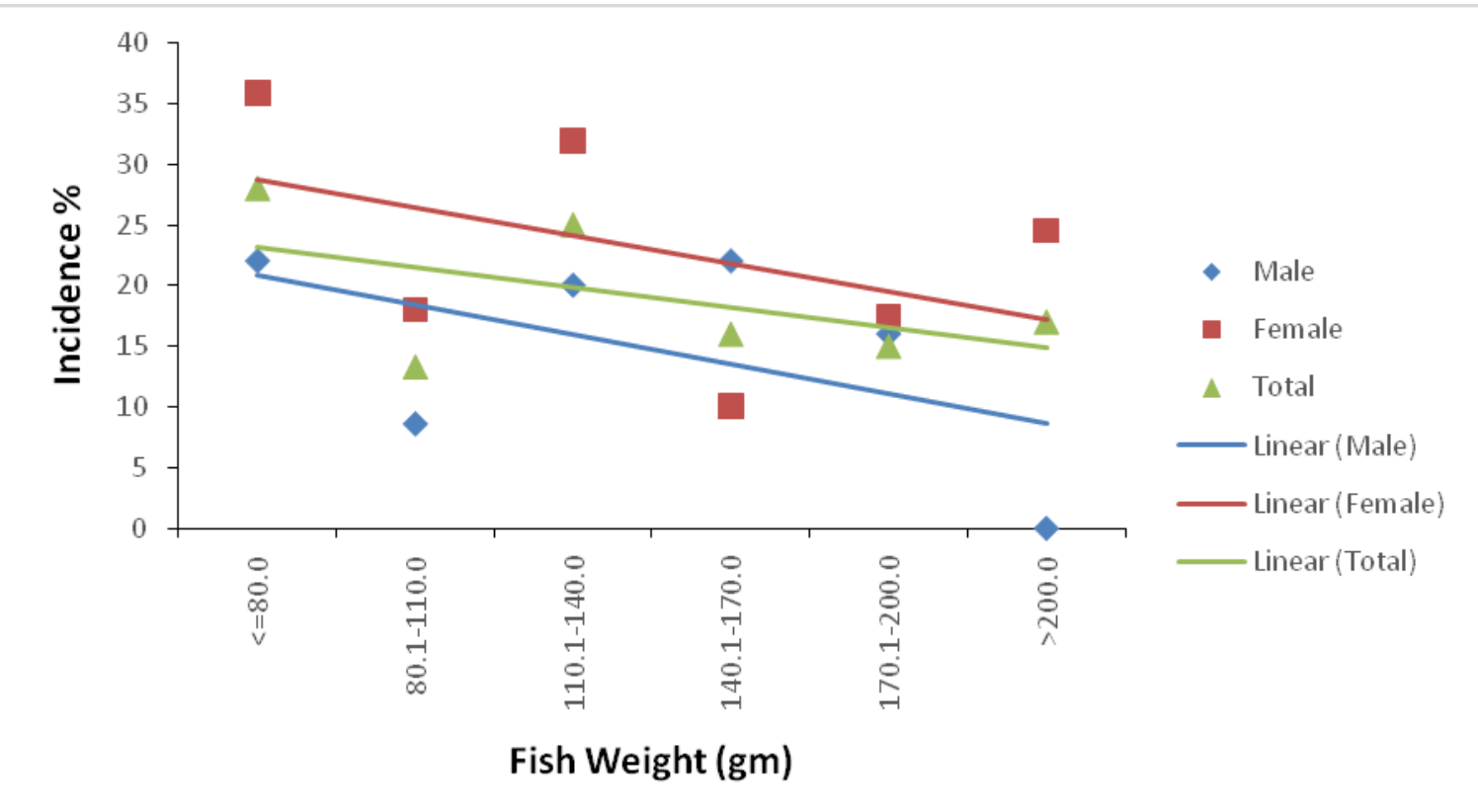

Fig 4 (a): Correlation of infection incidence of $F$. teleostei with weight of S. richardsonii during 2015-16

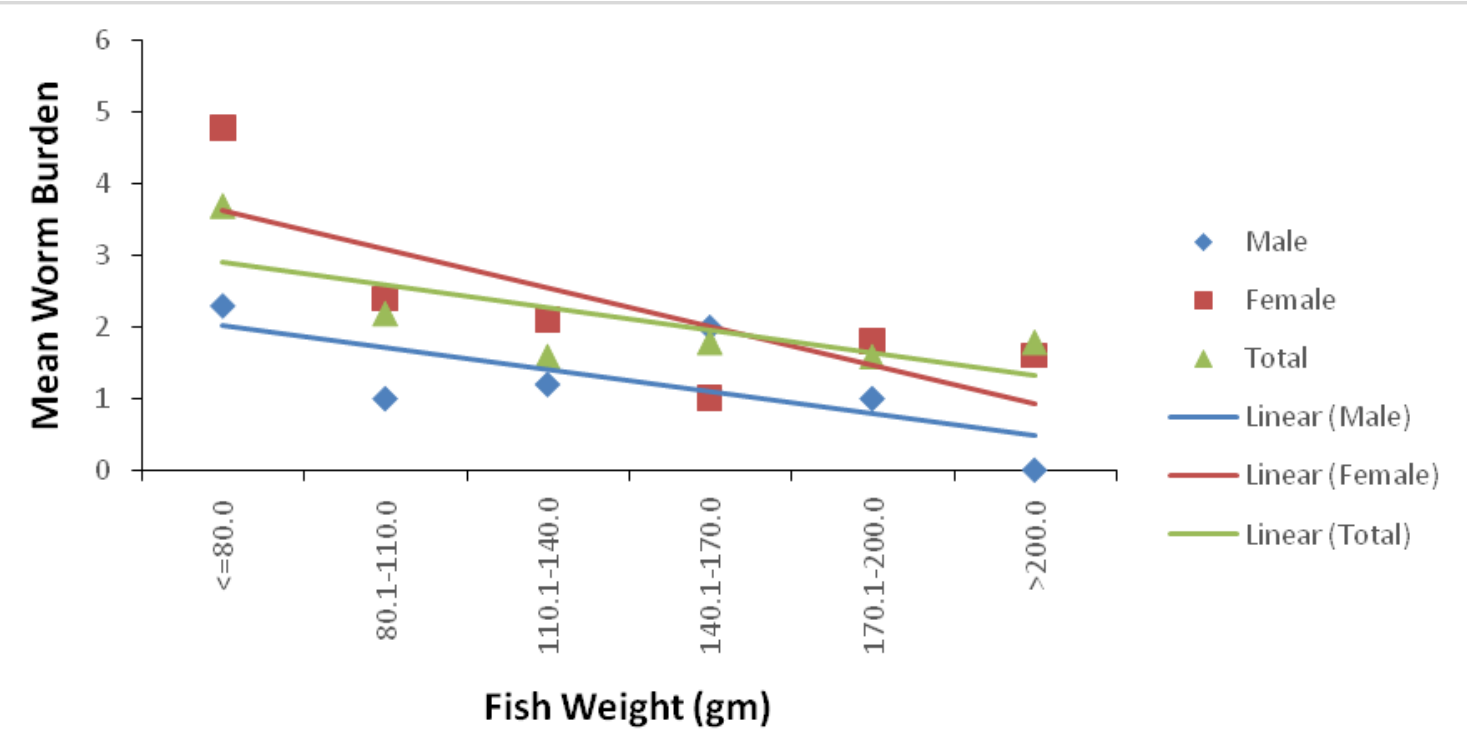

Fig 4 (b): Correlation of mean worm burden of F. teleostei with weight of S. richardsonii during 2015-16 


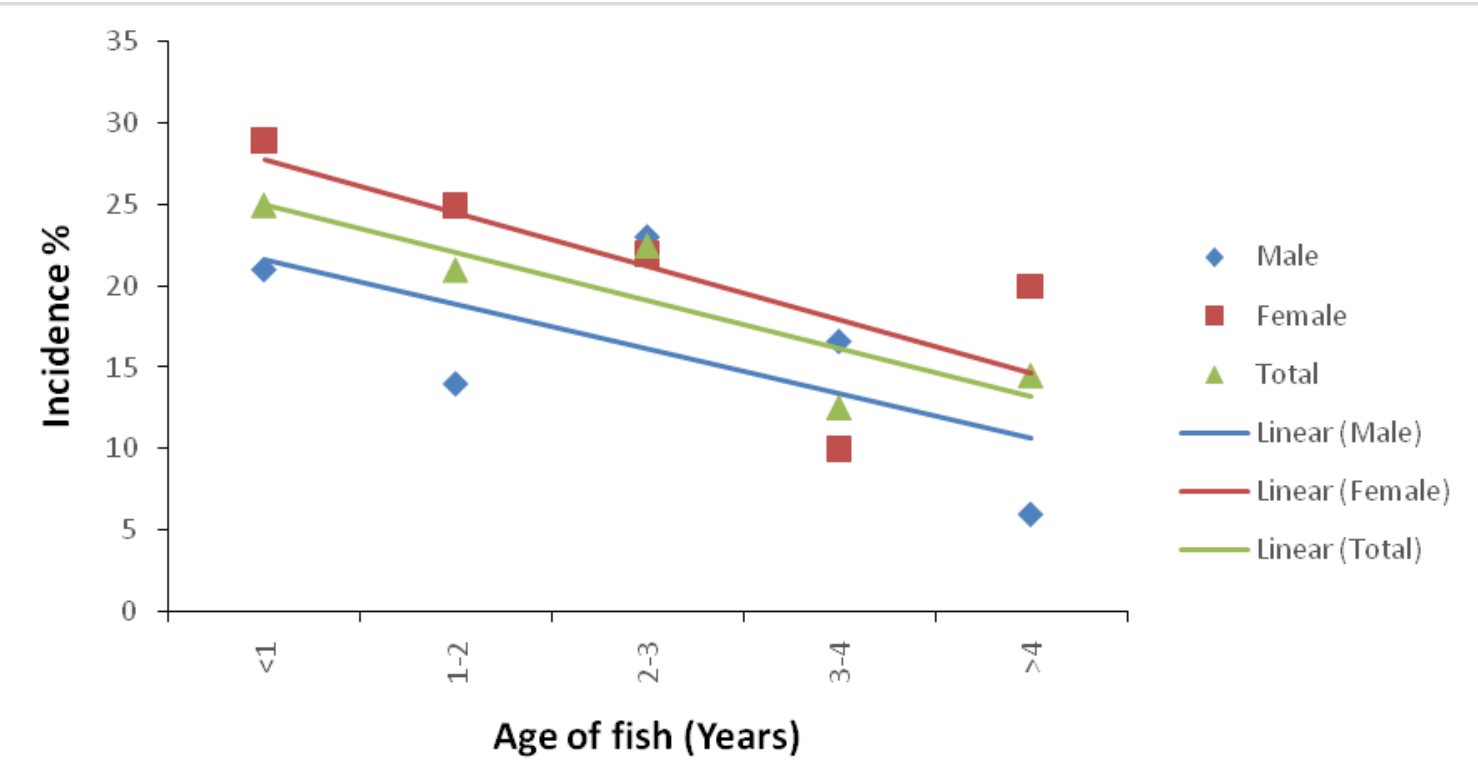

Fig 5 (a): Correlation of infection incidence of F. teleostei with age of S. richardsonii during 2014-16

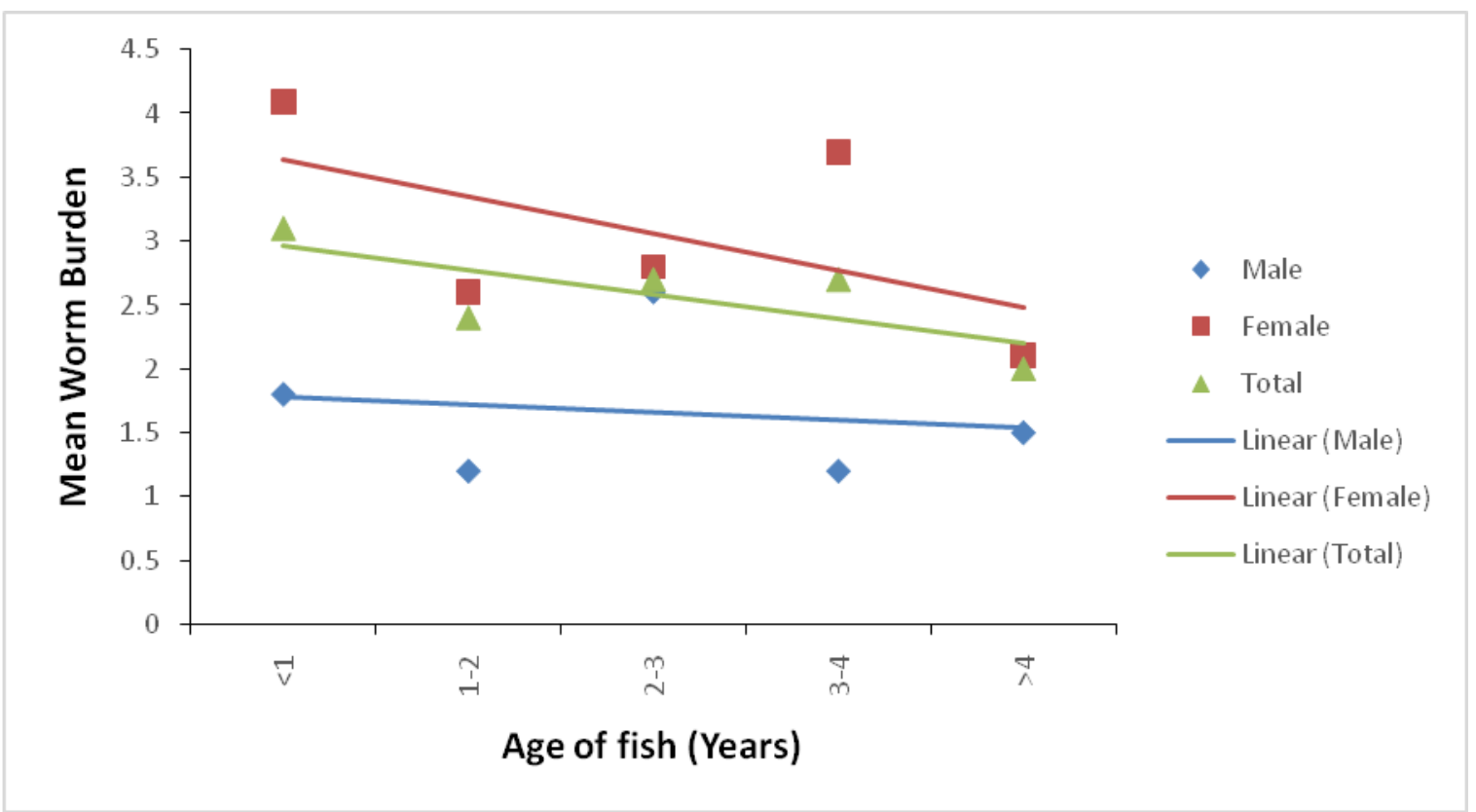

Fig 5 (b): Correlation of mean worm burden of F. teleostei with age of S. richardsonii during 2014-16

These results are supported by the study of Bothriocephalus claviceps infections in Perch in which Scholz (1986) reported maximum infection in middle size fishes, while very small or large fishes showed lesser susceptibility to bothriocephalid infections. This infection pattern may be the result of composition of food and age immunity. Davis and Huffman (1978) also reported more infestations in middle sized Gambusia affinis by 26 helminth species. Similar observations are also reported by Davey and Peachey (1968) for Bothriocephalus scorpii (Muller) in Turbot (Psetta maxima, L.). DeGroot (1971), Frandsen et al. (1989) suggested that an increase in the number of Philonema oncorhynchi in Salvelinus alpinus may be due to more frequent host parasite contact. Hoglund and Thulin (1989) also observed an increase in both prevalence and relative density of Paradiplozoon homoin infection in relation to host size in Sweden. Similar 
observations are reported by Marcogliase (1989), Robert et al. (1990), Saad-Fares and Combes (1992), Nie and Kennedy (1991) and Farhaduzzaman (2010). Levsen et al. (2017) reported significant positive relationship of parasite prevalence and abundance with host size/length in marine cultured fishes. $\mathrm{He}$ concluded that effect of body size on infection rate is related to change in the feeding habit of host.The occurrence of negative correlation i.e. an increase in the host's size with a reduction in the level of parasitism has been reported (Zdzitowiecki,1988, Oliva et al. 1990 and Iyaji et al. 2009). According to these authors the negative correlation may be due to changing in the feeding habit or development of immunity reaction that occurs in older fish (Adams, 1985). Age has often

\section{References}

Abiyu M Mekonnen G and Hailay K (2020) Prevalence of internal nematode parasites of Nile Tilapia (Oreochromis niloticus) fish species caught from southwestern part of Lake Tana, central Gondar, Ethiopia. J. Aquac. Res. Dev. 2: 1-7.

Adams AM (1985) Parasites on the gills of the Plains Killifish, Fundulus kansae, in the South Platte River, Nebraska. Trans. Amer. Micros. Soc.104: 278-284.

Anderson R and Gordon D (1982) Processes influencing the distribution of parasite numbers within the host populations with special emphasis on parasite induced host mortalities. Parasitology. 8:373-398.

Arme, C and Owen RW (1967) Infections on the three spined Stickleback Gastrosteus aculeatus L. with the pleurocercoid larvae of Schistocephalus solidus (Muller,1776), with reference to pathological effects. Parasitology 57: 301-314.

Borowik MM (1968) Dynamics of infection of various age groups of Alburnus alburnus L. in the Zegrzynski reservoir. Acta Parasitologica Polonica XV 42:321-332.

Chandler M Chapman LJ and Chapman CA (1995) Patchiness in the abundance of been found to be positively associated with prevalence and intensity of parasite infection (Madhavi and Rukmini,1991, Chandler et al. 1995). Poulin (2000) stated that in the fish population parasitic infection tends to increase with increasing host age and size. He argued that older fish have longer time to accumulate parasites than younger ones. Results of our study are in accordance with that of Pennycuick (1971), Anderson and Gordon (1982) and Gordon and Rau (1982). They argued that the lower prevalence in larger individuals may be due to the development of immunity with age. In the authors view there may be two possibilities for decrease in infection in larger host; age immunity and stronger host resistance developed by larger fishes and change in feeding habit in larger fishes.

metacercariae parasitizing Poecilia gillii (Poeciliidae) isolated in pooles of an intermittent tropical stream. Environ. Biol. Fishes. 42:313-321.

Chauhan RS (1982) "Some ecological and morphometric studies of cestode parasites from fishes of district Pauri Garhwal (U.P.)". D.Phil. Thesis, University of Garhwal.

Davey JT and Peachey JE (1968) Bothriocephalus scorpii (Cestoda:Pseudophyllidea) in turbot and brill from British coastal waters. J. Mar. Biol. Assoc. UK 48: 335-340.

Davis JR and Huffman DJ (1978) Some factors associated with the distribution of helminths among individual mosquito fish, Gambusia affinis. Texas J. Sci. 30: 43-53.

De Groot SJ (1971) On the interrelationship between morphology of alimentary tract, food and feeding behavior in flat fishes (pisces: pleuronectiformes). Neth. J. Sea Res. 5: 121-126.

Farhaduzzaman AM Alam MM Hossain MA and Rahman MH (2010) Prevalence of parasites in the Indian Major Carp, Lnbeo rohita (Hamilton) in Rajshahi, Bangladesh. Univ. J. Zool. Rajshahi. Univ. 28: 65-68.

Frandsen F Malmquist HJ and Snorrason SS (1989) Ecological parasitology of polymorphic Arctic charr, Salvelinus alpinus 
(L.) in Thingvallavatn, Iceland. J. Fish Biol. 34: 282-297.

Gordon DM and Rau ME (1982) Possible evidence of mortality induced by the parasite, Apatemon gracilis in a population of brook sticklebacks, Culea inconstans. Parasitology. 84: 41-47.

Hoglund J and Thulin J (1989) Thermal effects on the thermal dynamics of Paradiplozoon homoin (Bychowsky and Nagibina, 1959) parasitizing roach, Rutilus rutilus (L.). J. Helminthol. 63: 93-101.

Iyaji FO Etim L and Eyo JE (2009) Parasite Assemblages in Fish Hosts. Bio-Research. 7(2): 561-570.

Iwanowicz DD (2011) Overview on the effects of parasites on fish health. Report of Leetown Science Centre, US Geological Survey.

Kennedy CR and Walker PJ (1969) Evidences for an immune response by dace, Leuciscus leuciscus to infections by the cestode Caryophillaeus laticeps. J. Parasitol. 55: 579582.

Khanum H Bugum N and Begum A (2011) Seasonal prevalence, intensity and organal distribution of helminth parasites in Macrognathus aculeatus. Dhaka Univ.J. Biol. Sci. 20(2): 117-122.

Khanum H and Parveen S (1997) Organal distribution and seasonal prevalence of endoparasites in Macrognathus aculeatus Smith and Macrognathus armatus Day. Bangladesh J. Zool. 25(1): 15-21.

Lawrence JL (1970) Effects of season on host age and sex on endohelminths of Catostomus commersoni. J. Parasitol. 56: 567-571.

Levsen A Svanevik CS Cipriani P Mattiucci S Gay M Hastie LC Buselic I Mladineo I Karl H Ostermeyer U Buchmann K Hojgaard DP Gonzalez AF Pascual S and Pierce GJ (2017) A survey of zoonotic nematodes of commercial key fish species from major Europian fishing grounds-Introducing the FP7 PARASITE exposure assessment study. Fish. Res.. 1-18.

Lux Fred E (1971) Age determination of fishes. United States natural Fishery Services.
(Published by United States Development of Commerce). Fishery leaflet no. 488: 1-11.

Macrogliese DJ and Esch GW (1989) Alterations in seasonal dynamics of Bothriocephalus acheilognathi in a North Carolina cooling reservoir over a seven year period. $J$. Parasitol. 75: 378-382.

Madhavi R and Rukmini C (1991) Population biology of the metacercariae of Centrocestus formosanus (Trematoda: Heterophyidae) on the gills of Aplocheilus panchax. J. Zool. 223: 509-520.

Malhotra SK, Chauhan RS and Capoor VN (1980) Nematode infection in relation to some ecological aspects of hill-stream fishes. Geobios 8: 260-263.

Nie P and Kennedy CR (1991) The population biology of Camallanus lacustris (Zoega) in eels, Anguilla anguilla and their status as its host. J. Fish Biol. 38: 653-661.

Oliva M, Luque JL and Innacone JA (1990) The metazoan parasites of Stellifer minor (Tschudi, 1844): an ecological approach. Revista Brasileira de Biologia. 60(4): 577584.

Parveen S and Sultana S (2014) Infestation of helminth parasites in Gangetic leaffish Nandus nandus (Hamilton, 1822) Bangladesh J. Zool. 42(2): 183-190.

Pennycuick L (1971) Differences in the parasite infections in three-spined sticklebacks Gastrosteus aculeatus L. of different sex, age and size. Parasitology. 63: 407-418.

Poulin R (2000) Variation in the intraspecific relationship between fish length and intensity of the parasitic infection: Biological and statistical causes. J. Fish Biol. 58: 123-137.

Robert F, Boy V and Gabrion C (1990) Biology of parasite populations: population dynamics of Bothriocephalus (Cestoda-Pseudophyllidea) in teleostean fish. J. Fish Biol. 27: 327-342.

Saad-Fares A and Combes C (1992) Abundance/host size relationship in a fish trematode community. J. Helminthol. 66: 187-192.

Scholz T (1986) Observations on the ecology of five species of internal helminthes in Perch 
(Perca fluviatilis) from the Macha Lake fish pond system, Czechoslovakia. Vest cs spolec Zool. 50: 300-320.

Singh OV and Malik BS (1990) Effect of size, weight and age of host on the infection patters of Paraqimperia pectinopteri in Glyptothorax pectinopterus (McClelland). In: Environ. Pollut. \& Health Hazards. 133-137.

Singh OV and Malik BS (1992) Nematode fauna of hill-stream fishes: Filochona teleostei n. sp. from Schizothorax richardsonii (GRAY). Bioved 3(1): 31-34.

Sharma I and Mehta HS (2010) Studies on Snow Trout Schizothorax richardsonii (Gray) in river Beas and its tributaries (Himachal Pradesh), India. Rec. Zool. Surv. India, Occ. paper no. 323: 1-69. (Published by Director, Zool. Surv. of India, Kolkata).

Smyth JD (1962) An Introduction to Animal Parasitology ( $1^{\text {st }}$ ed.). 470 Pp. Engl. Univ. Press London.

Snedecor GW and Cochran WG (1968) Statistical methods. 593pp. Oxford and IBH Publishing Company, New Delhi.

Thomas JD (1964) A comparison between helminth burdens of male and female brown trout, Salmo trutta L. from natural populations in the River Teifi, West Wales. Parasitology 54: 263-272.

Zdzitowiecki K (1988) Occurence of digenetic trematodes in fishes of South Shetlands (Antarctic). Acta parasitologica Polonica. 33:155-167.

$$
* * * * * * * * *
$$

